\title{
Immune response and disease resistance of Oreochromis mossambicus to Aeromonas hydrophila after exposure to hexavalent chromium
}

\author{
M. Prabakaran ${ }^{1}$, C. Binuramesh ${ }^{1}$, D. Steinhagen ${ }^{2}$, R. D. Michael ${ }^{1, *}$ \\ ${ }^{1}$ Centre for Fish Immunology, Postgraduate and Research Department of Zoology, Lady Doak College, Madurai 625002, \\ Tamil Nadu, India \\ ${ }^{2}$ Fish Disease Research Unit, Centre for Infection Medicine, School of Veterinary Medicine, Bünteweg 17, \\ 30559 Hannover, Germany
}

\begin{abstract}
The objective of this study was to investigate the effect of chronic exposure to sublethal concentrations of hexavalent chromium $\left(\mathrm{K}_{2} \mathrm{Cr}_{2} \mathrm{O}_{7}\right)$ on the immune response and disease resistance of Oreochromis mossambicus (Peters) to bacterial Aeromonas hydrophila infection. Fish (45 to $50 \mathrm{~g}$ ) were exposed to $0.005,0.05,0.5$, and $5 \mathrm{mg} \mathrm{l}^{-1}\left[0.01,0.1,1\right.$, and $10 \% \mathrm{LC}_{50}$, respectively] of hexavalent chromium $\mathrm{Cr}$ (VI) for $28 \mathrm{~d}$. The specific immune response was assessed by antibody response to $A$. hydrophila by bacterial agglutination assay, and to sheep red blood cells (SRBC) by plaque forming cell (PFC) assay. In addition, nonspecific immune mechanisms were assessed by serum lysozyme activity and reactive nitrogen intermediates, the latter in terms of nitric oxide (NO) production by peripheral blood leucocytes. Overall immunity was assessed by disease resistance against live virulent $A$. hydrophila. The study clearly indicated that chronic exposure of fish to 0.5 and $5 \mathrm{mg} \mathrm{l}^{-1}$ of chromium (VI) decreased both nonspecific and specific parameters of the immune system, which resulted in a lower disease resistance to $A$. hydrophila. Interestingly, $0.05 \mathrm{mg} \mathrm{l}^{-1}$ of $\mathrm{Cr}$ (VI) enhanced disease resistance and both nonspecific and specific immune responses to A. hydrophila. Our study revealed a concentration-dependent modulation of the immune system by chromium (VI), as demonstrated by suppressive or stimulatory effects on lymphocytes, lysozyme, phagocytic killing mechanisms, and disease resistance in $O$. mossambicus.
\end{abstract}

KEY WORDS: Chromium $\cdot$ Exposure $\cdot$ Disease resistance $\cdot$ Lysozyme $\cdot$ Nitric oxide $\cdot$ Oreochromis mossambicus $\cdot$ Antibody response

\section{INTRODUCTION}

The aquatic environment of fish is influenced by a number of factors of both anthropogenic and natural origin. Many of these factors ultimately affect the fish homeostatic mechanism and thereby lead to energy exhaustion. This in turn negatively affects the energydemanding process of immunity and increases susceptibility to disease. Chromium is one of the highly prevalent industrial pollutants in developing countries such as India (Khwaja et al. 2001). The most significant anthropogenic sources of chromium in waterways are leather tanning industries, electroplating operations, and textile manufacturing industries (ATSDR 2000). Among these, the leather-tanning industry is the major source of chromium deposition in Indian waterways (Khwaja et al. 2001). Almost $90 \%$ of tanning units in India are situated along the banks of rivers, where the concentration of hexavalent chromium has been found to range from 3.0 to $11.2 \mathrm{mg} \mathrm{l}^{-1}$, far in excess of the permissible limit of $0.5 \mathrm{mg} \mathrm{l}^{-1}$ (Dubey et al. 2001, Koteswari \& Ramanibai 2003, Tare et al. 2003).

In the aqueous environment, chromium has 2 ionic forms: hexavalent chromium $\mathrm{Cr}$ (VI) and trivalent chromium $\mathrm{Cr}$ (III). The former is widely used in industrial processes and is more toxic than $\mathrm{Cr}$ (III) (Blasiak \& 
Kowalik 2000). Cr (VI) readily penetrates cell membranes and becomes reduced to more stable $\mathrm{Cr}$ (III). The reduction process of $\mathrm{Cr}$ (VI) to $\mathrm{Cr}$ (III) results in the formation of reactive intermediates that may cause DNA damage, membrane damage, and altered gene expression (Ye et al. 1999). On the other hand, Cr (III) is an essential component of human and animal nutrition and is required for energy metabolism (Anderson 1997). Several studies have investigated the effect of $\mathrm{Cr}$ (VI) on the immune system of different fish species. Chromium has been shown to suppress the humoral immune response against the viral MS2 bacteriophage in Salmo trutta L. and Cyprinus carpio L. (O'Neill 1981). Khangarot et al. (1999) have shown that exposure of the freshwater catfish Saccobranchus fossilis to sublethal levels of $\mathrm{Cr}$ (VI) compromises the humoral and cell mediated immunity by decreasing levels of antibody and splenic plaque forming cell number, by reducing proliferation of splenic lymphocytes, and by decreasing disease resistance to bacterial infection.

Chromium has also been found to suppress humoral immunity in Oreochromis mossambicus (Arunkumar et al. 2000). Reports on the effect of $\mathrm{Cr}$ (VI) on the nonspecific immune mechanisms of fish are very sparse. $\mathrm{Cr}$ (VI) affects various components of the immune system by immunosuppression or immunostimulation in both Wistar rats (Glaser et al. 1985) and humans (Borella et al. 1990). Furthermore, several reports demonstrate that dietary supplementation of $\mathrm{Cr}$ (III) or (VI) enhances immune responses in dairy cows by enhancing serum immunoglobulin production and antibody titres to antigens or vaccines, and by reducing serum cortisol concentration (Moonsie-Shageer \& Mowat 1993, Chang et al. 1996). The objective of our study was to investigate the effect of chronic exposure to sublethal concentrations of $\mathrm{Cr}$ (VI) on disease resistance and nonspecific and specific immune responses in O. mossambicus.

\section{MATERIALS AND METHODS}

Fish. Oreochromis mossambicus, procured from a local farmer, were acclimated to ambient, uncontrolled laboratory water temperature $\left(28 \pm 2^{\circ} \mathrm{C}\right)$ under natural photoperiod for $2 \mathrm{wk}$ in $165 \mathrm{l}$ fiber reinforced plastic tanks. All tanks were fitted with a separate water recirculation system with external biofilters (Eheim-2213) with a flow rate of $71 \mathrm{~min}^{-1}$. Male fish weighing 45 to $50 \mathrm{~g}$ were used in the present study. All fish were fed once a day ad lib. with a balanced diet (protein: $39 \%$; carbohydrate: $24 \%$; lipid: $11 \%$; water: $10 \%$; ash: $9 \%$; trace amounts of vitamins and minerals) prepared in the laboratory. Physico-chemical characteristics of the water were monitored and maintained.
Chromium exposure. Groups of fish were exposed to $0.005,0.05,0.5$, or $5 \mathrm{mg} \mathrm{l}^{-1}\left(0.01,0.1,1\right.$, or $\left.10 \% \mathrm{LC}_{50}\right)$ of $\mathrm{Cr}$ (VI) for $28 \mathrm{~d}$. After this period, fish continued to be held in chromium spiked water until sampling was completed. The specific immune response was assessed by antibody response to Aeromonas hydrophila using bacterial agglutination assay, and by number of antibody producing cells against SRBC using plaque forming cell (PFC) assay. To ascertain the complete primary antibody response, fish were sampled until Day 56 (until Day 28 post immunization). For PFC assay, fish were sampled until Day 43 (until Day 15 post immunization). Nonspecific immune mechanisms were assessed by serum lysozyme activity and reactive nitrogen intermediates, via assessment of nitric oxide (NO) production by peripheral blood leucocytes. To ascertain the nonspecific parameters, fish were sampled until Day 38. Overall immunity was assessed as the degree of resistance against live virulent $A$. hydrophila.

Serum separation. For serum separation, $200 \mu \mathrm{l}$ of blood was drawn from the cardinal vein (Michael et al. 1994) and collected in serum tubes. Blood was allowed to clot overnight at $20^{\circ} \mathrm{C}$, and was then centrifuged at $400 \times g$ for $10 \mathrm{~min}$ and the serum was separated. Serum was stored in sterile eppendorf tubes at $-20^{\circ} \mathrm{C}$ until further use. For bacterial agglutination assay, the serum was de-complemented by incubation at $47^{\circ} \mathrm{C}$ for $30 \mathrm{~min}$ in a water bath (Sakai 1981).

Bacterial agglutination assay. For detecting the effect of chromium exposure on antibody response, 8 fish per group were maintained. Fish were administered intraperitoneally with heat killed Aeromonas hydrophila bacterin, containing $1 \times 10^{8}$ cells in $0.2 \mathrm{ml}$ of phosphate buffered saline (PBS) per fish (Karunasagar et al. 1997) after $28 \mathrm{~d}$ of chromium exposure. An unimmunized control was also maintained. All fish were repetitively bled at regular intervals of $7 \mathrm{~d}$ post immunization until Day 28. Antibody titres against heat killed A. hydrophila were performed in 96 well ' $\mathrm{V}$ ' bottom microtitre plates after Sakai et al. (1993) with slight modifications: $25 \mu \mathrm{l}$ of serum was added to the first well and 2-fold serial dilutions were made with PBS, before $25 \mu \mathrm{l}$ of heat killed A. hydrophila suspension $\left(1 \times 10^{9}\right.$ cells ml $\left.^{-1}\right)$ pre-stained with crystal violet was added to each well. The microtitre plate was incubated at $37^{\circ} \mathrm{C}$ overnight. The highest dilution of serum sample that showed detectable macroscopic agglutination was recorded and expressed as $\log _{2}$ antibody titre of the serum (Roberson 1990).

Plaque forming cell (PFC) assay. To study the effect of chronic exposure to $\mathrm{Cr}$ (VI) on the number of antibody producing cells, 15 fish group ${ }^{-1}$ were maintained. All fish were primed (injected) intraperitoneally with $0.1 \mathrm{ml}$ of $5 \%$ SRBC after $28 \mathrm{~d}$ of exposure. A booster dose of 
$0.1 \mathrm{ml}$ of $25 \%$ SRBC was then administered through the same route after 3 d (Venkatalakshmi \& Michael 2001). The direct PFC assay (Anderson 1990) was performed to determine the number of PFC. Five fish group ${ }^{-1}$ were killed on Days 5, 10, and 15 post immunization using excessive dose of MS-222, and the spleen was aseptically excised. By forcing the spleen through $100 \mu \mathrm{m}$ nylon mesh, spleen cells were isolated. Cells were washed in RPMI 1640 and adjusted to $1 \times 10^{7}$ cells ml $^{-1}$. From the cell suspension, $100 \mu$ l were mixed in a serological tube along with $200 \mu \mathrm{l}$ of $10 \%$ SRBC in RPMI 1640, $100 \mu$ of $1.5 \%$ solution of warm $\left(45^{\circ} \mathrm{C}\right)$ agarose and $100 \mu \mathrm{l}$ of RPMI 1640 media, and were then poured immediately on to a glass microscope slide. Slides were incubated at $28^{\circ} \mathrm{C}$ for $4 \mathrm{~h}$, then $500 \mu \mathrm{l}$ of $10 \%$ guinea pig serum was added as a source of complement. Slides were further incubated for $2 \mathrm{~h}$ at $28^{\circ} \mathrm{C}$. The numbers of PFC per slide were enumerated by observation under a dissection microscope at $5 \times$ magnification.

Serum lysozyme assay. For the lysozyme assay, 8 fish group ${ }^{-1}$ were maintained. All fish were repetitively bled at regular intervals of 2 d until Day 38, beginning after $28 \mathrm{~d}$ of chromium exposure. A serum sample had also been taken $2 \mathrm{~d}$ prior to chromium exposure. Serum lysozyme assay was determined using a turbidimetric assay developed by Parry et al. (1965) with the microplate adaptation of Hutchinson \& Manning (1996). A suspension of $0.3 \mathrm{mg} \mathrm{ml}^{-1}$ of Micrococcus lysodeikticus in $0.05 \mathrm{M}$ sodium phosphate buffer ( $\mathrm{pH}$ 6.2) was used as substrate; $10 \mu \mathrm{l}$ of serum was added to $250 \mu \mathrm{l}$ of the bacterial suspension, and reduction in absorbance at $490 \mathrm{~nm}$ was determined after 0.5 and $4.5 \mathrm{~min}$ of incubation at $28^{\circ} \mathrm{C}$ in a microplate reader (Model 680, Biorad). One unit of lysozyme activity was defined as a reduction in absorbance of $0.001 \mathrm{~min}^{-1}$ (Ellis 1990).

Preparation of peripheral blood leucocytes. Blood was collected by cardinal vein puncture (Michael et al. 1994) into syringes filled with blood collecting medium (RPMI 1640 supplemented with $5 \times 10^{4} \mathrm{IU} \mathrm{l}^{-1}$ sodium heparin, $10^{5} \mathrm{IU} \mathrm{l}^{-1}$ penicillin, and $100 \mathrm{mg} \mathrm{l}^{-1}$ streptomycin). Peripheral blood leucocytes (PBL) were separated from erythrocytes by centrifugation $(800 \times g$, $20 \mathrm{~min}$ ) over Lymphoprep (Nycomed) as described by Miller \& McKinney (1994). Cell suspensions were washed 3 times with washing medium (RPMI 1640 supplemented with $10^{5} \mathrm{IU} \mathrm{l}^{-1}$ sodium heparin, $10^{5} \mathrm{IU} \mathrm{l}^{-1}$ penicillin, and $100 \mathrm{mg} \mathrm{l}^{-1}$ streptomycin) for $10 \mathrm{~min}$ at $700 \times g$ and resuspended in culture medium (RPMI 1640 supplemented with $3 \%$ [v/v] of pooled, heat inactivated $\left(30 \mathrm{~min}, 47^{\circ} \mathrm{C}\right)$ tilapia serum, $10^{5} \mathrm{IU} \mathrm{l}^{-1}$ penicillin, $100 \mathrm{mg} \mathrm{l}^{-1}$ streptomycin, and $4 \mathrm{mM}$ L-glutamine) (all chemicals: Biochrom AG). Numbers of viable cells (exclusion of trypan blue) were enumerated and adjusted to $4 \times 10^{7} \mathrm{ml}^{-1}$ using cell culture medium.
Reactive nitrogen intermediates production assay. To study the effect of chronic exposure to $\mathrm{Cr}$ (VI) on the reactive nitrogen intermediates (RNI) in terms of nitric oxide (NO) production, 5 fish were maintained. Fish were exposed to different concentrations of $\mathrm{Cr}$ (VI) for $28 \mathrm{~d}$. After this period, NO production was estimated by using peripheral blood leucocytes at regular intervals of $2 \mathrm{~d}$ until Day 38. Preparation of leucocytes was performed as described before. The release of NO by peripheral blood leukocytes in the medium was measured using Griess reaction. The Griess reagent indicates the presence of nitrite as a surrogate of NO (Green et al. 1982). Peripheral blood leukocytes were cultured for $96 \mathrm{~h}$ at $28^{\circ} \mathrm{C}$ and $50 \mu \mathrm{l}$ culture supernatant was collected and transferred to a separate microtitre plate; $50 \mu \mathrm{l}$ of Griess reagent (1\% sulphanilamide, $0.1 \%$ N-Naphthyl-ethylenediamine, $2.5 \%$ phosphoric acid) was then added to each well containing the culture supernatant. After incubation for $10 \mathrm{~min}$, the optical density was recorded spectrophotometrically at $570 \mathrm{~nm}$. Molar concentrations of $\mathrm{NO}_{2}$ were calculated from a standard curve generated from a graded series of $\mathrm{NaNO}_{2}{ }^{-}$concentrations in culture medium.

Disease resistance test. To study the effect of Cr (VI) on disease resistance, groups of fish $\left(\mathrm{n}=30\right.$ group $\left.^{-1}\right)$ were exposed to $0.005,0.05,0.5$, or $5 \mathrm{mg} \mathrm{l}^{-1}$ of $\mathrm{Cr}$ (VI) for $28 \mathrm{~d}$. These groups (in duplicate) were experimentally challenged with $\mathrm{LD}_{30}$ dose $(0.2 \mathrm{ml}$ PBS containing $1 \times 10^{8}$ cells) of live virulent Aeromonas hydrophila. Previously, fish had been administered a wide range of doses of $A$. hydrophila (ranging from $1 \times 10^{5}$ to $1 \times$ $10^{9}$ cells $0.2 \mathrm{ml}^{-1} \mathrm{PBS}$ ) to determine the rate of mortality over time. Mortality was observed until Day 28 post infection, but no mortality was observed after $96 \mathrm{~h}$ of administration. Thus, in this experiment, time of exposure to the $\mathrm{LD}_{30}$ dose was set at $96 \mathrm{~h}$. The average of the duplicate set was used to express percent mortality.

Statistics. Data were expressed as arithmetic mean \pm SE. Student's 2-tailed $t$-test and 1-way analysis of variance (ANOVA) were used to test significant differences between and among groups, respectively, using Sigmastat 2.0 (Jandel Corporation). Differences were considered significant when $\mathrm{p}<0.05$.

\section{RESULTS}

\section{Effect of Cr (VI) on antibody response}

While the antibody response expressed as $\log _{2}$ of the agglutination titre was comparable among all groups $7 \mathrm{~d}$ after immunization, on Day 14 post immunization clear differences were evident (Fig. 1). A significant reduction compared to the control was found in groups previously exposed to $0.5 \mathrm{mg} \mathrm{l}^{-1}$ or $5 \mathrm{mg} \mathrm{l}^{-1}$ of $\mathrm{Cr}$ (VI) 


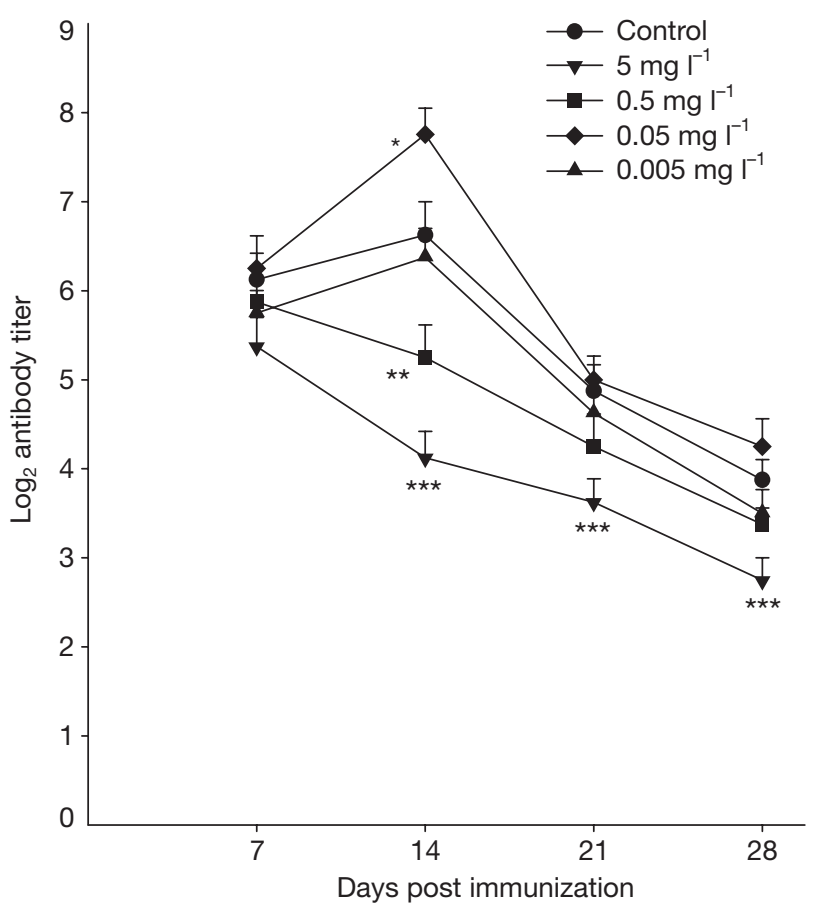

Fig. 1. Oreochromis mossambicus. Effect of chronic exposure to $\mathrm{Cr}$ (VI) on antibody response to heat killed Aeromonas hydrophila, assayed by bacterial agglutination. Points represent mean $+\mathrm{SE}_{;} \mathrm{n}=8$ group $^{-1} ;{ }^{\star} \mathrm{p}<0.05 ;{ }^{* \star} \mathrm{p}<0.02 ;{ }^{\star \star *} \mathrm{p}<0.01$

( $p<0.05$ and $p<0.01$, respectively), while the titre significantly increased in the group exposed to $0.05 \mathrm{mg} \mathrm{l}^{-1}$ of $\mathrm{Cr}(\mathrm{VI})(\mathrm{p}<0.05)$. On Day 21 and 28, fish exposed to $5 \mathrm{mg} \mathrm{l}^{-1}$ of $\mathrm{Cr}(\mathrm{VI})$ showed a significant $(\mathrm{p}<0.01)$ suppression of antibody titre.

\section{Effect of Cr (VI) on PFC numbers}

The number of antibody producing cells visualized as PFC were comparable among all groups $5 \mathrm{~d}$ after SRBC injections (Fig. 2). However, on Day 10 post SRBC injection, clear differences were evident among groups. A significant $(\mathrm{p}<0.01)$ reduction in PFC numbers compared to the control was observed in groups previously exposed to $0.5 \mathrm{mg} \mathrm{l}^{-1}$ or $5 \mathrm{mg} \mathrm{l}^{-1}$ of $\mathrm{Cr}(\mathrm{VI})$, while the PFC number significantly increased in the group exposed to $0.05 \mathrm{mg} \mathrm{l}^{-1}$ of $\mathrm{Cr}(\mathrm{VI})(\mathrm{p}<0.05)$. On Day 15, the group exposed to $5 \mathrm{mg} \mathrm{l}^{-1}$ of $\mathrm{Cr}$ (VI) showed a significant $(\mathrm{p}<0.01)$ reduction in $\mathrm{PFC}$ number.

\section{Effect of $\mathrm{Cr}$ (VI) on serum lysozyme activity}

Serum lysozyme activity was comparable among all groups on Day 30, while exposure to $5 \mathrm{mg} \mathrm{l}^{-1}$ of $\mathrm{Cr}$ (VI) significantly decreased the serum lysozyme activity on all the other days tested ( $p<0.01$ ) (Fig. 3). A significant

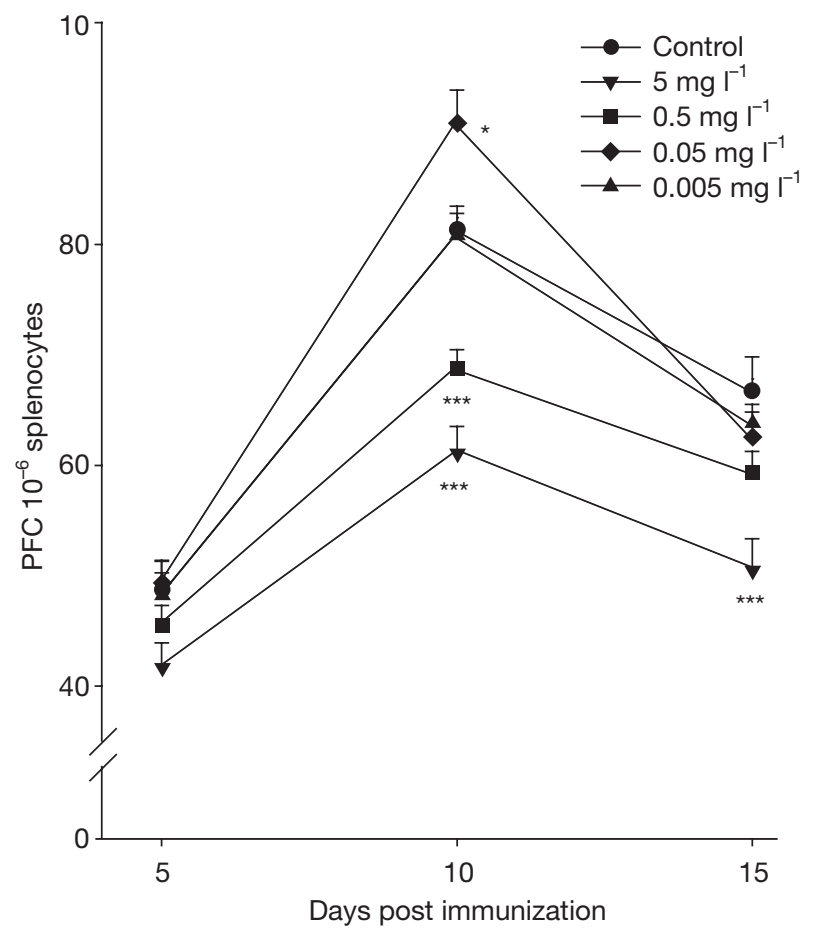

Fig. 2. Oreochromis mossambicus. Effect of chronic exposure to $\mathrm{Cr}$ (VI) on number of plaque forming cells (PFC). Points represent mean $+\mathrm{SE}_{;} \mathrm{n}=5 \operatorname{group}^{-1} ;{ }^{*} \mathrm{p}<0.05 ;{ }^{* *} \mathrm{p}<0.02$;

$$
{ }^{\star * \star} \mathrm{p}<0.01
$$

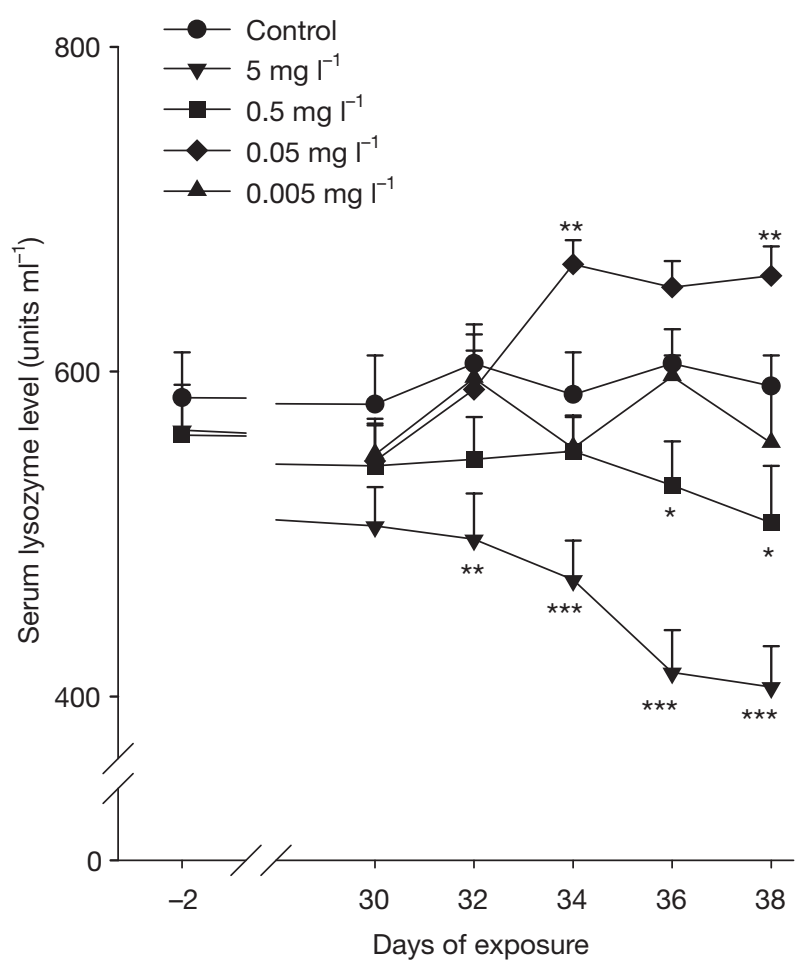

Fig. 3. Oreochromis mossambicus. Effect of chronic exposure to $\mathrm{Cr}$ (VI) on serum lysozyme level. Points represent mean $+\mathrm{SE} ; \mathrm{n}=8 \operatorname{group}^{-1} ;{ }^{\star} \mathrm{p}<0.05 ;{ }^{\star \star} \mathrm{p}<0.02 ;{ }^{\star \star \star} \mathrm{p}<0.01$ 
reduction in serum lysozyme activity on Days 36 and 38 was also observed in the group exposed to $0.5 \mathrm{mg} \mathrm{l}^{-1}$ of $\mathrm{Cr}$ (VI) ( $\mathrm{p}<0.05)$. Exposure to $0.05 \mathrm{mg} \mathrm{l}^{-1}$ of $\mathrm{Cr}(\mathrm{VI})$ resulted in significant $(p<0.02)$ enhancement of serum lysozyme activity on Day 34 and 38.

\section{Effect of Cr (VI) on RNI production}

The RNI was measured as NO production by peripheral blood leucocytes (Fig. 4). Significant reduction in NO production was observed on Day 30 and 38 (p < 0.01 and $p<0.05$, respectively) in the group exposed to the highest concentration, i.e. $5 \mathrm{mg} \mathrm{l}^{-1} \mathrm{Cr}$ (VI). Exposure to $0.5 \mathrm{mg} \mathrm{l}^{-1}$ of $\mathrm{Cr}$ (VI) significantly ( $\mathrm{p}<0.05$ ) reduced the production only on Day 30. Exposure to lower concentrations $\left(0.05 \mathrm{mg} \mathrm{l}^{-1}\right.$ and $0.005 \mathrm{mg} \mathrm{l}^{-1)} \mathrm{did}$ not have any significant effect on the NO production on any day of testing.

\section{Effect of $\mathrm{Cr}$ (VI) on disease resistance to Aeromonas hydrophila}

Disease resistance was expressed as $96 \mathrm{~h}$ percent mortality. Fish exposed to higher concentrations of $\mathrm{Cr}$ (VI) (either 5 or $0.5 \mathrm{mg} \mathrm{l}^{-1}$ ) showed increased percent mortality (75.9 and $56.1 \%$, respectively) when admin-

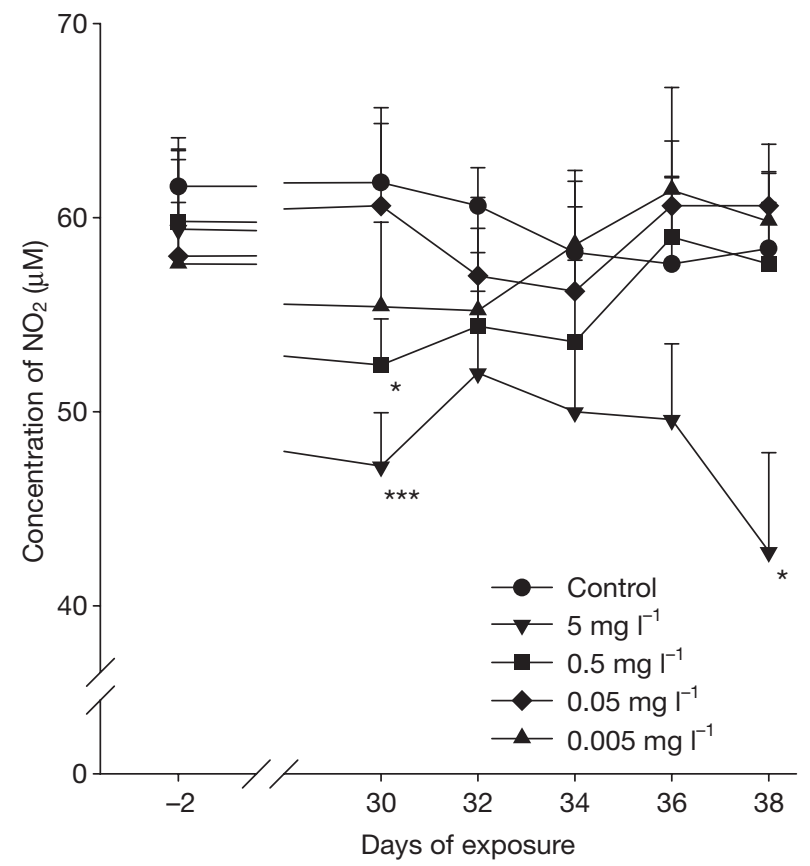

Fig. 4. Oreochromis mossambicus. Effect of chronic exposure to $\mathrm{Cr}$ (VI) on reactive nitrogen intermediates (RNI) in terms of $\mathrm{NO}_{2}$ secretion by peripheral blood leucocytes. Points represent mean $+\mathrm{SE}_{;} \mathrm{n}=5$ group $^{-1} ;{ }^{*} \mathrm{p}<0.05$ ${ }^{\star \star} \mathrm{p}<0.02 ;{ }^{\star \star \star} \mathrm{p}<0.01$ istered with Aeromonas hydrophila (Fig. 5). Interestingly, fish exposed to $0.05 \mathrm{mg} \mathrm{l}^{-1}$ of $\mathrm{Cr}$ (VI) exhibited decreased percent mortality $(13.2 \%)$ when compared to control fish not exposed to Cr (VI) (percent mortality $33.33 \%$ ). However, the lowest concentration of $\mathrm{Cr}$ (VI) tested $\left(0.005 \mathrm{mg} \mathrm{l}^{-1}\right)$ had no effect on percent mortality compared to the control.

\section{DISCUSSION}

The present study clearly shows that chronic exposure to sublethal concentrations of $\mathrm{Cr}$ (VI) has an immunomodulatory effect on the immune response of Oreochromis mossambicus.

The results of experiments on antibody response indicated that chronic exposure to 0.5 or $5 \mathrm{mg} \mathrm{l}^{-1}$ (1 or $10 \% \mathrm{LC}_{50}$ ) of $\mathrm{Cr}(\mathrm{VI})$ significantly suppressed antibody titres against heat killed Aeromonas hydrophila (Fig. 1). Similar findings have been reported on the reduction of hemagglutination titers against SRBC in the fresh water catfish Saccobranchus fossilis exposed to 0.1 to $3.2 \mathrm{mg} \mathrm{l}^{-1}$ of $\mathrm{Cr}$ (VI) for $28 \mathrm{~d}$ (Khangarot et al. 1999). Sugatt (1980) demonstrated that juvenile coho salmon Oncorhynchus kisutch exposed to $\mathrm{Cr}$ (VI) for $14 \mathrm{~d}$ had suppressed agglutinating antibody titers against Vibrio anguillarum. Arunkumar et al. (2000) demonstrated the suppression of antibody response to bovine serum albumin (BSA) in Oreochromis mossambicus after intraperitoneal injection of $\mathrm{Cr}$ (VI). It has been suggested that the suppressive effect might be due to the interaction of chromium with lymphocyte

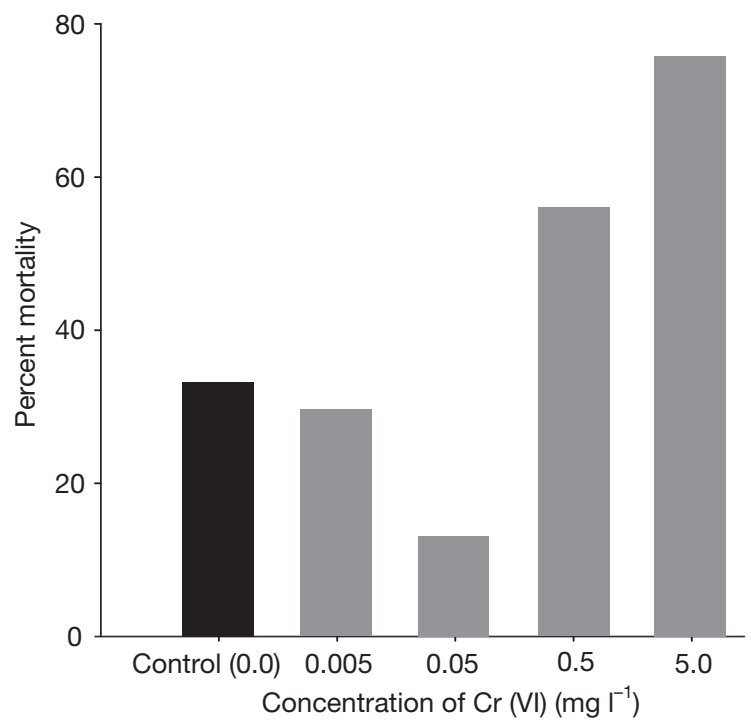

Fig. 5. Oreochromis mossambicus. Effect of chronic exposure to $\mathrm{Cr}$ (VI) on disease resistance to live virulent Aeromonas hydrophila, expressed as percent mortality after $96 \mathrm{~h} ; \mathrm{n}=30$ group $^{-1}$ 
cell surface proteins, which thereby alters the response of those cells to various stimuli (Snyder \& Valle 1991). Further, chromium has been shown to react with cell surface receptors for mitogen, block lymphocyte proliferation, and inhibit immunoglobulin production (Koller 1980, Borella et al. 1990).

In contrast to the above-mentioned observations, chronic exposure to a lower concentration of $0.05 \mathrm{mg} \mathrm{l}^{-1}$ $\left(0.1 \% \mathrm{LC}_{50}\right)$ of $\mathrm{Cr}(\mathrm{VI})$ significantly enhanced the antibody titre to heat killed Aeromonas hydrophila (Fig. 1). Viale \& Calamari (1984) observed that concentrations of $\mathrm{Cr}$ (VI) ranging from 0.05 to $0.2 \mathrm{mg}^{-1}$ had no effect on the humoral immune response of rainbow trout. Our study provides the first report on immunostimulatory effect of prolonged exposure to a lower concentration of Cr (VI) (0.05 $\mathrm{mg} \mathrm{l}^{-1}$ ) on the antibody response in fish. However, this observation is in agreement with studies on mammalian animal models. Moonsie-Shageer \& Mowat (1993) reported enhanced primary immune response to human red blood cells (HRBCs) in stressed feeder calves fed diets supplemented with $0.2,0.5$ or $1.0 \mathrm{mg} \mathrm{l}^{-1}$ of $\mathrm{Cr}(\mathrm{VI})$. An enhancement of anti-ovalbumin antibody response has also been observed in stressed feeder calves fed with chromium-supplemented feed (Burton et al. 1993). These authors also reported that a diet supplemented with chelated chromium improved antibody titers against infectious bovine rhinotracheitis virus after vaccination.

Lymphocytes producing specific antibodies in spleen of fish can be identified and enumerated by PFC assay. The experiment on the effect of $\mathrm{Cr}$ (VI) on antibody producing cells indicated that the number of PFC decreased following chronic exposure to concentrations of 0.5 and $5 \mathrm{mg} \mathrm{l}^{-1}$ (Fig. 2). Similar suppressive effects on PFC have been observed in Saccobranchus fossilis following exposure to sublethal concentrations of $\mathrm{Cr}$ (VI) ranging from 0.1 to $3.2 \mathrm{mg} \mathrm{l}^{-1}$ for $28 \mathrm{~d}$ (Khangarot et al. 1999). These authors also reported that in vitro exposure to $\mathrm{Cr}$ (VI) inhibited mitogen induced T-lymphocyte proliferation in spleen and pronephros of $S$. fossilis. It has been suggested that Cr (VI) ions might react with fish splenic and pronephric cell surface proteins, thereby blocking the responses of cells to various stimuli and also inhibiting lymphocyte proliferation (Khangarot et al. 1999).

Here again, chronic exposure to $0.05 \mathrm{mg} \mathrm{l}^{-1}$ of $\mathrm{Cr}$ (VI) significantly increased the number of PFC (Fig. 2). Earlier studies show that splenocytes isolated from rats exposed to chromium in drinking water exhibited enhanced proliferative response to T- and B-lymphocyte mitogens (Snyder \& Valle 1991). Kegley et al. (1996) reported that supplementary $\mathrm{Cr}$ in the form of Cr-nicotinic acid enhanced the blastogenic response of feeder calves to phytohemagglutinin (PHA)-stimulated lymphocytes, and also that concanavalin A-induced lymphocyte proliferation was enhanced in chromium (Cr-yeast) supplement-fed cows (Burton et al. 1993). Similarly, van Heugten \& Spears (1997) reported increased pokeweed mitogen (PWM) stimulated lymphocyte blastogenesis in pigs fed $\mathrm{Cr}$ (VI) or $\mathrm{Cr}$ (III) picolinate-supplemented feed. From the above reports, it is evident that trace levels of chromium can enhance the mitogen-induced proliferation of $\mathrm{T}$ - and B-lymphocytes. Chang et al. (1996) reported that dietary supplementation of chromium enhanced lymphocyte proliferation in dairy cows, and that this might be associated with chromium and insulin interactions.

Snyder \& Valle (1991) reported that Cr (VI) stimulated spontaneous thymidine uptake by rat lymphocytes at concentrations of $0.1 \mathrm{mg} \mathrm{l}^{-1}$, but inhibited uptake at concentrations greater than 0.1 and up to $100 \mathrm{mg} \mathrm{l}^{-1}$. They also reported that T- and B-lymphocyte counts decreased in Wistar rats supplied with $200 \mathrm{mg} \mathrm{l}^{-1} \mathrm{Cr}$ (VI) in their drinking water, whereas counts increased in rats supplied $100 \mathrm{mg} \mathrm{l}^{-1} \mathrm{Cr}$ (VI). Thus, our study clearly demonstrated and confirmed that the immunosuppressive or stimulatory effect of $\mathrm{Cr}$ (VI) is dependent on concentration.

Serum lysozyme activity was used as a parameter to assess the influence of chronic exposure to $\mathrm{Cr}$ (VI) on the humoral component of the nonspecific defense mechanism of Oreochromis mossambicus. Sanchez-Dardon et al. (1999) reported that heavy metal pollution affects lysozyme levels and causes alterations of immunoregulatory functions in fish. Our study revealed that chronic exposure to 0.5 or $5 \mathrm{mg} \mathrm{l}^{-1}$ of $\mathrm{Cr}$ (VI) suppressed serum lysozyme activity. In contrast, chronic exposure to $0.05 \mathrm{mg} \mathrm{l}^{-1}$ of $\mathrm{Cr}$ (VI) enhanced serum lysozyme activity (Fig. 3). This substantiates the observations of Gatta et al. (2001) that a low level of dietary organic chromium supplementation enhanced the serum lysozyme level in rainbow trout. They reported that both the duration of feeding and the level of supplemented chromium influenced the modulation of lysozyme level. Our study indicated that both positive and negative influences of Cr (VI) on serum lysozyme activity exist.

Campos-Perez et al. (2000) reported that secretion of NO by activated macrophages of rainbow trout inhibits bacterial infection. Results from our study on the effect of chromium on RNI in terms of NO production revealed that chronic exposure to 5 and $0.5 \mathrm{mg} \mathrm{l}^{-1}$ of $\mathrm{Cr}$ (VI) suppressed NO production (Fig. 4). Steinhagen et al. (2004) reported a similar suppression of NO secretion during in vitro exposure of head kidney leucocytes of carp Cyprinus carpio to $20 \mu \mathrm{mol} \mathrm{l^{-1 }} \mathrm{Cr}$ (VI) over $96 \mathrm{~h}$. Tian \& Lawrence (1996) reported that chromium suppressed the activity of an NO-producing enzyme (inducible NO synthase) in murine macrophages. Our study revealed negative modulation of RNI production in response to elevated levels of $\mathrm{Cr}(\mathrm{VI})$. 
Disease resistance was used to assess the overall integrated or combined specific and nonspecific immune mechanisms. Our study demonstrated that chronic exposure to 0.5 or $5 \mathrm{mg} \mathrm{l}^{-1}$ of $\mathrm{Cr}$ (VI) decreased the disease resistance to Aeromonas hydrophila infection (Fig. 5). The percentage mortality of fish increased in a dose-dependent manner from concentrations of $0.5 \mathrm{mg} \mathrm{l}^{-1}$ to $5 \mathrm{mg} \mathrm{l}^{-1}$. Several studies demonstrated an increased mortality of fish after viral or bacterial administration following chromium exposure. Khangarot et al. (1999) reported that Saccobranchus fossilis exposed to 1.0 or $3.2 \mathrm{mg} \mathrm{l}^{-1} \mathrm{Cr}$ (VI) for $28 \mathrm{~d}$ and administered with live Aeromonas hydrophila exhibited higher mortality than control fish. A similar increase in mortality was reported after exposure of coho salmon Oncorhynchus kisutch to $0.5 \mathrm{mg} \mathrm{l}^{-1} \mathrm{Cr}$ (VI) for $14 \mathrm{~d}$ and challenged with live Vibrio anguillarum (Sugatt 1980). This increase in fish mortality observed in the present investigation was probably due to suppression of nonspecific immune mechanisms.

Interestingly, in our investigation, chronic exposure to $0.05 \mathrm{mg} \mathrm{l}^{-1}\left(0.1 \% \mathrm{LC}_{50}\right)$ of $\mathrm{Cr}(\mathrm{VI})$ increased the disease resistance to Aeromonas hydrophila when compared to that of the unexposed control group. Kegley et al. (1996) reported that dietary supplementation of chromium nicotinic acid complex or chromium chloride in feeder calves subjected to physical stress increased the disease resistance against infectious bovine rhinotracheitis virus in young calves. There are no earlier literature reports on chromium treatment increasing disease resistance against bacterial infection in fish. Thus, ours is the first report that prolonged exposure to $\mathrm{Cr}$ (VI) has an hormesis-like stimulation of the immune response in fish, i.e. that it is beneficial at lower concentrations and detrimental at higher concentrations.

The most salient conclusion that can be drawn from our study is that, depending on concentration, Cr (VI) modulates the immune response in either a suppressive or a stimulatory manner as shown by its action on lymphocytes, lysozyme, and phagocytic killing mechanisms. These findings may be important when monitoring fish health and risk assessment during periods of fluctuating chromium concentrations in both natural and farm environments.

Acknowledgements. The study was supported by grants from the Volkswagen foundation, Hannover, Germany, and the Council of Scientific Industrial Research (CSIR), India.

\section{LITERATURE CITED}

Anderson DP (1990) Passive haemolytic plaque assay for detecting antibody producing cells in fish. In: Stolen JS, Fletcher TC, Anderson DP, Roberson BS, van Muiswinkel
WB (eds) Techniques in fish immunology. SOS Publications, New Haven, NJ, p 9-12

Anderson RA (1997) Chromium as an essential nutrient for humans. Regul Toxicol Pharmacol 26:35-41

Arunkumar RI, Rajasekaran P, Michael RD (2000) Differential effect of chromium compounds on the immune response of the African mouthbreeder Oreochromis mossambicus (Peters). Fish Shellfish Immunol 10:667-676

ATSDR (Agency for Toxic Substance and Disease Registry) (2000) Toxicological profile for chromium. ATSDR PB93182434, Atlanta, GA

Blasiak J, Kowalik J (2000) A comparison of the in vitro genotoxicity of tri- and hexavalent chromium. Mutat Res 469: 135-145

Borella P, Manni S, Giardino A (1990) Cadmium, nickel, chromium and lead accumulate in human lymphocytes and interfere with PHA-induced proliferation. J Trace Elem Electrolytes Health Dis 4:87-95

Burton JL, Mallard BA, Mowat DN (1993) Effects of supplemental chromium on immune responses of peripaturient and early lactation dairy cows. J Anim Sci 71:1532-1539

Campos-Perez JJ, Ward M, Grabowski PS, Ellis AE, Secombes CJ (2000) The gills are an important site of iNOS expression in rainbow trout Oncorhynchus mykiss after challenge with the Gram-positive pathogen Renibacterium salmoninarum. Immunology 99:153-161

Chang X, Mallard BA, Movat DN (1996) Effects of chromium on health status, blood neutrophil, phagocytosis and in vitro lymphocyte blastogenisis of dairy cows. Vet Immunol Immunopathol 52:37-52

Dubey CS, Sahoo BK, Nayak NR (2001) Chromium (VI) in waters in parts of Sukinda Chromite Valley and health hazards, Orissa, India. Bull Environ Contam Toxicol 67: $541-548$

Ellis AE (1990) Lysozyme assays. In: Stolen JS, Fletcher TC, Anderson DP, Roberson BS, van Muiswinkel WB (eds) Techniques in fish immunology. SOS Publications, New Haven, NJ, p 101-103

Gatta PP, Thompson KD, Smullen R, Piva ST, Adams A (2001) Dietary organic chromium supplementation and its effect on the immune response of rainbow trout (Oncorhynchus mykiss). Fish Shellfish Immunol 11:371-382

Glaser U, Hochrainer D, Kloppel H, Kuhnen H (1985) Low level chromium (VI) inhalation effects on alveolar macrophages and immune functions in Wistar rats. Arch Toxicol 57:250-256

Green LC, Wagner DA, Glogowski J, Skipper PL, Wishnok JS, Tannenbaum S (1982) Analysis of nitrate, nitrite and $\left({ }^{15} \mathrm{~N}\right)$ nitrate in biological fluids. Anal Biochem 126:131-138

Hutchinson TH, Manning MJ (1996) Seasonal trends in serum lysozyme activity and total protein concentration in dab (Limanda limanda L.) sampled from Lyme Bay, UK. Fish Shellfish Immunol 6:473-482

Karunasagar I, Ali A, Otta SK, Karunasagar I (1997) Immunisation with bacterial antigens: infections with motile aeromonas. Dev Biol Stand 90:135-141

Kegley EB, Spears JW, Brown TT (1996) Immune response and disease resistance of calves fed chromium nicotinic acid complex or chromium chloride. J Dairy Sci 79: 1278-1283

Khangarot BS, Rathore RS, Tripathy DM (1999) Effects of chromium on humoral and cell-mediated immune responses and host resistance to disease in a freshwater catfish, Saccobranchus fossilis (Bloch). Ecotoxicol Environ Saf 43:11-20

Khwaja AR, Rashmi singh, Tandon SN (2001) Monitoring of Ganga water and sediments vis-à-vis tannery pollution at 
Kanpur (India): a case study. Environ Monit Assess 68: 19-35

Koller LD (1980) Immunotoxicology of heavy metals. Int J Immunopharmacol 2:269-279

Koteswari YN, Ramanibai R (2003) The effect of tannery effluent on the colonization rate of plankters: a microcosm study. Turk J Biol 27:163-170

Michael RD, Srinivas SD, Sailendri K, Muthukkaruppan VR (1994) A rapid method for repetitive bleeding in fish. Indian J Exp Biol 32:838-839

Miller NW, Mc Kinney EC (1994) In vitro culture of fish leukocytes. In: Hochachka PW, Mommsen TP (eds) Biochemistry and molecular biology of fishes, Vol 3. Elsevier, Amsterdam, p 341-353

Moonsie-Shageer S, Mowat DN (1993) Effect of level of supplemental chromium on performance, serum constituents and immune status of stressed feeder calves. J Anim Sci 71:232-238

O'Neill JG (1981) The humoral immune response of Salmo trutta L. and Cyprinus carpio L. exposed to heavy metals. J Fish Biol 19:297-306

Parry RM, Chandan RC, Shahani KM (1965) A rapid and sensitive assay of muramidase. Proc Soc Exp Biol 119: 384-386

Roberson BS (1990) Bacterial agglutination. In: Stolen JS, Fletcher TC, Anderson DP, Roberson BS, van Muiswinkel WB (eds) Techniques in fish immunology. SOS Publications, New Haven, NJ, p 81-86

Sakai DK (1981) Heat inactivation of complements and immune hemolysis reactions in rainbow trout, masu salmon, coho salmon, goldfish and tilapia. Bull Jap Soc Sci Fish 47:565-571

Sakai M, Atsuta S, Kobayashi M, Kawakami H, Yoshida T (1993) The cell surface hydrophobicity and hemagglutinating properties of the bacterial fish pathogen, Pasteurella piscicida. Bull Eur Assoc Fish Pathol 13:168-170

Editorial responsibility: Thomas Braunbeck, Heidelberg, Germany
Sanchez-Dardon J, Voccia I, Hontela A, Chilmonczyk S, Dunier M, Boermans H., Blakely B, Fournier M (1999) Immunomodulation by heavy metals tested individually or in mixtures in rainbow trout (Oncorhynchus mykiss) exposed in vivo. Environ Toxicol Chem 18:1492-1497

Snyder CA, Valle CD (1991) Lymphocyte proliferation assays as potential biomarkers for toxicant exposures. J Toxicol Environ Health 34:127-139

Steinhagen D, Helmus T, Maurer S, Michael RD, Leibold W, Scharsack JP, Skouras A, Schuberth HJ (2004) Effect of hexavalent carcinogenic chromium on carp Cyprinus carpio immune cells. Dis Aquat Org 62:155-16

Sugatt RH (1980) Effects of sodium dichromate exposure on the immune response of juvenile coho salmon (Oncorhynchus kisutch) against Vibrio angullarum. Arch Environ Contam Toxicol 9:207-216

Tare V, Gupta S, Bose P (2003) Case studies on biological treatment of tannery effluents in India. J Air Waste Manage Assoc 53:976-982

Tian L, Lawrence DA (1996) Metal-induced modulation of nitric oxide production in vitro by murine macrophages: lead, nickel and cobalt utilize different mechanisms. Toxicol Appl Pharmacol 141:540-547

van Heugten E, Spears JW (1997) Immune response and growth of stressed weanling pigs fed diets supplemented with organic or inorganic forms of chromium. J Anim Sci 75:409-416

Venkatalakshmi S, Michael RD (2001) Immunostimulation by leaf extract of Ocimum sanctum Linn. in Oreochromis mossambicus (Peters). J Aquac Trop 16:1-10

Viale G, Calamari D (1984) Immune response in rainbow trout Salmo gairdneri after long-term treatment with low levels of $\mathrm{Cr}, \mathrm{Cd}$ and $\mathrm{Cu}$. Environ Pollut A 35:247-257

Ye J, Wang S, Leonard SS, Sun Y and 7 others (1999) Role of reactive oxygen species and p53 in chromium (IV)induced apoptosis. J Biol Chem 274:37974-37980

Submitted: April 29, 2004; Accepted: October 24, 2005 Proofs received from author(s): February 3, 2006 